[Radiocarbon, Vol. 18, No. 2, 1976, P. 240-247]

\title{
VIENNA RADIUM INSTITUTE RADIOCARBON DATES VII
}

\author{
HEINZ FELBER
}

Institut für Radiumforschung und Kernphysik der Österr Akademie der Wissenschaften, Vienna, Austria

Measurements have continued with the same proportional counter system, pretreatment procedure, methane preparation and measurement, and calculation, as described previously ( $\mathrm{R}, 1970$, v 12, p 298-318). Uncertainties quoted are single standard deviations originating from standard, sample, background counting rates and half-life. No ${ }^{13} \mathrm{C} /{ }^{12} \mathrm{C}$ ratios were measured.

The following list represents most samples of our work in the last year. Sample descriptions have been prepared in cooperation with submitters.

\section{ACKNOWLEDGMENTS}

I express my thanks to Ing L Stein for excellent work in sample preparation, and to $\mathrm{H}$ Friedmann for careful operation of the dating equipment.

\section{SAMPLE DESCRIPTIONS}

I. GEOLOGY, GLACIOLOGY, LIMNOLOGY AND FORESTRY

\section{Freibach series, Kärnten}

\section{A. Austria}

Remnants of wood and cones, deformed and dark colored, in sandymuddy sediments of small dammed former lake, over-ridden by Freibach glacier and covered by moraine (van Husen, 1975). A palynologic profile was taken from each end of the 2 sedimentation basins separated by small alluvial cone. Samples coll at lower and upper end of profiles ca $3 \mathrm{~m}$ high. Left border of R Freibach (46 $\left.29^{\prime} 18^{\prime \prime} \mathrm{N}, 14^{\circ} 26^{\prime} 47^{\prime \prime} \mathrm{E}\right) \mathrm{S}$ of bridge Pt 812 (ÖK 1:25,000 Part 212/1 Zell Pfarre), Carinthia. Coll 1974 and subm by D van Husen, Inst Geol, TH Vienna.

General Comment (DvH): should help to clarify discrepancy between pollen analysis and age implied by VRI-393 (R, 1975, v 17, p 248).

VRI-418. Profile N, base

Cones and wood, lower end of Profile N.

$\begin{array}{cc} & 35,300 \\ \text { VRI-419. Profile N, top } & -2600 \\ -2600 \\ 33,300 \text { вC }\end{array}$

Cones and wood, upper end of Profile N.

$$
33,400+1600
$$

$31,400 \mathrm{BC}$

33,300 BC 
VRI-420. Profile S, base

Wood, lower end of Profile S.

\section{VRI-421. Profile S, top}

Cones and wood, upper end of Profile S.

VRI-398. Langenzersdorf, Nö

Stem of tree $3 / 73$ (willow?) lifted during excavation for lock Langenzersdorf $\left(48^{\circ} 20^{\prime} \mathrm{N}, 16^{\circ} 20^{\prime} \mathrm{E}\right)$, Lower Austria, left bank of $\mathrm{R}$ Danube,

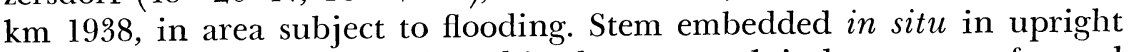
position with humic silt and sand in the root-stock in lower part of gravel zone ca 10m thick on flysh socket. Coll 1973 and subm by J Fink, Geog Inst, Univ Vienna. Comment (JF): dates gravel accumulation in narrow passage of $\mathrm{R}$ Danube between Mt Kahlengebirge and Mt Bisamberg.

\section{VRI-401. Badgastein 1, Salzburg}

$5480 \pm 100$

Root (Pinus $m u g o$ ) $50 \mathrm{~cm}$ below surface from bog of unknown thickness between 2 lakes Pochart $\left(47^{\circ} 05^{\prime} \mathrm{N}, 13^{\circ} 02^{\prime} 30^{\prime \prime} \mathrm{E}\right), 7.5 \mathrm{~km} \mathrm{SW}$ Badgastein, Salzburg, alt 2040m. Coll 1973 and subm by G Mutschlechner, Innsbruck. Comment (GM): clue to age of bog.

\section{VRI-402. Badgastein 2, Salzburg}

Charred wood from dump of old mine, ca $20 \mathrm{~cm}$ below sward cover; $8 \mathrm{~km}$ SW Badgastein $\left(47^{\circ} 02^{\prime} 45^{\prime \prime} \mathrm{N}, 13^{\circ} 05^{\prime} 30^{\prime \prime} \mathrm{E}\right)$, Salzburg, alt $2160 \mathrm{~m}$. Coll 1973 and subm by G Mutschlechner. Comment (GM): decades ago K Zschocke coll fragments of vessels, supposedly Roman, near this location. Date is not helpful.

\section{VRI-346. Tennengebirge, Salzburg}

$$
570 \pm 80
$$

Piece of resin on surface of peat-earth over limestone, Mt Tennengebirge, W part of edge $\left(47^{\circ} 33^{\prime} \mathrm{N}, 13^{\circ} 13^{\prime} \mathrm{E}\right)$, alt ca $2200 \mathrm{~m}$, Salzburg. Coll by $\mathrm{G}$ Abel, subm by $\mathrm{K}$ Ehrenberg, Paläont Inst, Univ Vienna. No sample pretreatment. Comment (KE): dates period of wood growth on plateau of Mt Tennengebirge.

VRI-410. Mariazell, Steiermark

$$
10,360 \pm 390
$$

$$
\mathbf{8 4 1 0 ~ B C}
$$

Wood at $-4.30 \mathrm{~m}$ in boring core from bottom of $\mathrm{L}$ Erlaufsee, $34 \mathrm{~m}$ below water level, near Mariazell ( $\left.47^{\circ} 49^{\prime} 35^{\prime \prime} \mathrm{N}, 15^{\circ} 05^{\prime} 12^{\prime \prime} \mathrm{E}\right)$, Styria. Coll 1974 and subm by M Bobek, Limnolog Inst, Österr Akad Wiss, Vienna. HCl pretreatment only. Comment (MB): dates organic base of lake. Shell sample. 


\section{VRI-411. Mariazell, Steiermark}

Peaty substance in zone of change from lake marl to peat 30 to $40 \mathrm{~cm}$ above base of $3.2 \mathrm{~m}$ thick bog, former part of lake Hechtensee $\left(47^{\circ} 46^{\prime} 58^{\prime \prime} \mathrm{N}, 15^{\circ} 14^{\prime}\right.$ 02" E), near Mariazell, Styria. Coll 1973 and subm by M Bobek. Comment (MB): dates organic base of Hechtensee.

\section{Ober-Etrach series, Steiermark}

Samples from succession of lake, depth to base $5.35 \mathrm{~m}$, near OberEtrach $\left(47^{\circ} 12^{\prime} \mathrm{N}, 14^{\circ} 00^{\prime} 04^{\prime \prime} \mathrm{E}\right)$, Styria. Coll 1973 and subm by E Schultze, Limnolog Inst, Österr Akad Wiss, Vienna. No humic acid extraction. Comment (ES): date palynologic events.

\section{VRI-412. 25 to $30 \mathrm{~cm}$}

$11,010 \pm 160$

Clayey gyttja 25 to $30 \mathrm{~cm}$ above base. Gyttja was dissolved by $\mathrm{NaOH}$, separated from clay, precipitated by $\mathrm{HCl}$, and dated. Comment (ES): dates reforestation after extreme glaciation.

\section{VRI-413. 60 to $75 \mathrm{~cm}$}

$10,230 \pm 140$

Peat-gyttja 60 to $75 \mathrm{~cm}$ above base. Comment (ES): dates climatic oscillation in late glacial.

\section{VRI-414. 95 to $105 \mathrm{~cm}$}

Eriophorum peat 95 to $105 \mathrm{~cm}$ above base. Comment (ES): dates 1 st rise of Picea abies.

\section{Baumkirchen series, Tirol}

Wood from undisturbed banded silt, NW part of pit Baumkirchen $\left(47^{\circ} 18^{\prime} 25^{\prime \prime} \mathrm{N}, 11^{\circ} 34^{\prime} 19^{\prime \prime} \mathrm{E}\right), \mathrm{N}$ Tyrol. Coll near Finds 1 and 2 and subm by F Fliri, Geog Inst, Univ Innsbruck.

General Comment $(\mathrm{FF})$ : verification of dates from upper part of working (Fliri et al, 1972; Felber, 1971).

\section{VRI-343. Find 25}

$27,300 \pm 1100$

Wood from alt $678 \mathrm{~m}$, coll 1972. Comment (HF): admixture of dead methane due to small sample size.

\section{VRI-394. Find 30}

$28,100 \pm 800$

Twigs from Hippophae rh from alt 663m; coll 1973.

\section{6,150 BC}

\section{Obergurgl series, Tirol}

Cyperaceous peat samples from different depths of bog Zirbenwaldmoor near Obergurgl $\left(46^{\circ} 51^{\prime} 30^{\prime \prime} \mathrm{N}, 11^{\circ} 01^{\prime} 14^{\prime \prime} \mathrm{E}\right)$, Tyrol. Coll 1974 
and subm by S Bortenschlager, Inst Bot Systematik Geobot, Univ Innsbruck. HCl pretreatment only.

General Comment (SB): samples date changes and oscillations in pollen diagram.

VRI-424. 90 to $100 \mathrm{~cm}$

$2120 \pm 80$

Depth 90 to $100 \mathrm{~cm}$. Comment $(\mathrm{SB})$ : dates 1 st human influence recognized by considerable NAP climax.

VRI-425. 120 to $130 \mathrm{~cm}$

$5920 \pm 100$

Depth 120 to $130 \mathrm{~cm}$. Comment (SB): dates considerable change.

\section{VRI-426. 150 to $160 \mathrm{~cm}$}

$6920 \pm 110$

4970 BC

Depth 150 to $160 \mathrm{~cm}$. Comment (SB): suggests correspondence of change with Frosnitz-Oscillation of Venediger area.

VRI-427. 210 to $220 \mathrm{~cm}$

$7950 \pm 120$

Depth 210 to $220 \mathrm{~cm}$. Comment (SB): dates slight change in profile.

VRI-428. 260 to $270 \mathrm{~cm}$

$7960 \pm 200$

$6010 \mathrm{BC}$

Depth 260 to $270 \mathrm{~cm}$. Comment (SB): pollen curves of indicators of open vegetation end at this depth.

\section{Lienz series I, Osttirol}

Pine wood from different horizons of bog Bärenlacke above Schlaiten near Lienz (46 $\left.51^{\prime} 50^{\prime \prime} \mathrm{N}, 12^{\circ} 39^{\prime} 10^{\prime \prime} \mathrm{E}\right)$, E-Tyrol, alt 1550m. Coll 1972 and subm by $\mathrm{F}$ Kral, Inst Waldbau, Hochsch Bodenkultur, Vienna.

General Comment (FK) dates characteristic points of pollen profile and solves problems of forest history. Dates as expected.

VRI-360. Depth $44 \mathrm{~cm}$

Sample embedded in Carex peat.

AD 1600

VRI-361. Depth $65 \mathrm{~cm}$

$800 \pm 70$

Sample embedded in carr peat.

VRI-362. Depth $75 \mathrm{~cm}$

AD 1150

Sample embedded in carr peat.

$1410 \pm 70$ AD 550

\section{Lienz series II, Osttirol}

Samples from depth $54 \mathrm{~cm}$ of nameless bog above Schlaiten near Lienz $\left(46^{\circ} 51^{\prime} 40^{\prime \prime} \mathrm{N}, 12^{\circ} 39^{\prime} \mathrm{E}\right)$, E-Tyrol, alt $1600 \mathrm{~m}$. Coll 1972 and subm by $\mathrm{F}$ Kral.

General Comment (FK, HF): samples date characteristic points of pollen profile and solves problems in forest history. Discrepancy in dates is 
paralleled in Schlatenkees series (R, 1971, v 13, p 130; Patzelt, 1973), which shows that wood deposited in bog can be older than embedding peat horizon.

VRI-363. Sample A

Pine wood in transition zone from Carex peat to carr peat.

\section{VRI-364. Sample B}

$$
1740 \pm 100
$$

Stratigraphically autochthonous charcoal in nearly continuous layer spread over same peat transition zone in which Sample A was deposited.

\section{Wolfsgruben series, Italy}

$$
\text { B. Italy, Spain }
$$

Lacustrine deposit in quartz-porphyritic depression within relict pine woodland, Signater Kopf, Mt Ritten, Wolfsgruben $\left(46^{\circ} 31^{\prime} \mathrm{N}, 11^{\circ} 25^{\prime}\right.$ 02" E), prov Bozen (Alto Adige), S Tyrol, Italy. Coll 1973 and subm by R Schmidt, Limnolog Inst, Österr Akad Wiss, Vienna.

General Comment (RS): dates palynologically recognized events.

\section{VRI-382. 240 to $255 \mathrm{~cm}$}

$6200 \pm 100$

Radizellen Sphagnum peat from depth 240 to $255 \mathrm{~cm}$. Comment (RS): dates immigration of Abies alba and Fagus silvatica.

\section{VRI-408. 465 to $470 \mathrm{~cm}$}

$8500 \pm 140$

Dy from depth 465 to $470 \mathrm{~cm}$. Comment (RS): dates 1 st climatic deterioration.

\section{VRI-403. Hierro, Canarias, Spain}

Carbonized pine-wood (root?) excavated from horizon of volcanic ash $1 \mathrm{~m}$ below recent soil. Numerous small remains of pine-wood coal in same horizon suggest that wood was burnt by deposition of hot ash. Pit near San Andres $\left(27^{\circ} 45^{\prime} \mathrm{N}, 14^{\circ} 15^{\prime} \mathrm{E}\right)$, I Hierro; Canarias, Spain; alt $1000 \mathrm{~m}$. Coll 1973 and subm by $\mathrm{H}$ Franz, Inst Bodenforschung, Hochsch Bodenkultur, Vienna. Comment (HF): dates youngest volcanic activity at I Hierro.

$$
\text { C. Asia }
$$

\section{VRI-390. Kathmandu, Nepal}

$14,050 \pm 250$

Humic sand horizon ca $10 \mathrm{~cm}$ thick between banded sand layers ca $10.5 \mathrm{~m}$ below surface. Kathmandu, airport terrace $\left(22^{\circ} 40^{\prime} \mathrm{N}, 85^{\circ} 33^{\prime}\right.$ E), Nepal. Coll 1972 by H Franz, subm by F Kral. Comment (FK): chronologic classification of pollen-analytically tested humus horizons. 
VRI-373. Wadi Hanifah, Saudi Arabia

Modern

Roots in sand of accumulation terrace in Wadi Hanifah $\left(24^{\circ} 30^{\prime} \mathrm{N}\right.$, $\left.46^{\circ} 45^{\prime} \mathrm{E}\right)$, Saudi Arabia. Coll and subm by J Zötl, Inst Min Tech Geol, TH Graz. Only HCl pretreatment. Comment (JZ): terrace free of plants. Submitter expected dating of terrace.

\section{VRI-405. Al Hassa, Saudi Arabia}

$8290 \pm 120$

Peat-coal with sand 50 to $100 \mathrm{~cm}$ below recent surface in area of oasis of Al Hassa $\left(25^{\circ} 30^{\prime} \mathrm{N}, 49^{\circ} 37^{\prime} \mathrm{E}\right)$, Saudi Arabia. Coll and subm by J Zötl. Comment (JZ): dates former bogs presumably present in this oasis during periods of high precipitation.

\section{VRI-406. Persian Gulf, Saudi Arabia}

$3990 \pm 90$

2040 BC

Shells in sandstone from surface of solidified shell bank, presently at sea level, Persian Gulf ( $\left.26^{\circ} 30^{\prime} \mathrm{N}, 50^{\circ} 03^{\prime} \mathrm{E}\right)$, E coast of Saudi Arabia. Coll 1973 and subm by J Zötl. Sample leached with HCl before dating. Comment (JZ): dates formation of recent breakers terrace lying below sea level at that time.

\section{VRI-442. Wadi Shabah, Saudi Arabia}

$$
2 \pm 0.4 \%
$$

modern

Crusts of calcareous sinter on boulders in conglomerate layer of fluvial terrace ca 50 to $70 \mathrm{~cm}$ below surface, Wadi Shabah $\left(26^{\circ} 15^{\prime} \mathrm{N}\right.$, $41^{\circ} 50^{\prime}$ E), Saudi Arabia. Coll and subm 1974 by J Zötl. Comment (JZ): dates accumulation terrace. An assumed recent activity of $85 \%$ modern (Münnich \& Vogel, 1959; Geyh \& Schillat, 1966) gives model age of $28,900 \pm 1300$; upper age limit $30,200 \pm 1300$ is obtained with $100 \%$ modern.

\section{As Sulb series, Saudi Arabia}

Stalactite embedded in duricrust (calcareous, solidified reddish sediment resembling sandstone) from roof of cave Dahl Abu Marwa near As Sulb $\left(26^{\circ} 30^{\prime} \mathrm{N}, 47^{\circ} 30^{\prime} \mathrm{E}\right)$, Shumman Plateau, Saudi Arabia. Coll 1974 and subm by J Zötl.

General Comment (JZ): helps in study of paleo-climate and morphogenesis of Shumman Plateau.

VRI-450. Stalactite

$<\mathbf{1 \%}$ modern

Piece of stalactite, $20 \mathrm{~mm}$ thick, chiseled out of duricrust. Comment (HF): recent activity $85 \%$ modern, usually assumed (Franke and Geyh, 1969) gives $>37,000 \mathrm{yr}$.

\section{VRI-451. Duricrust $\quad 1.6 \pm 0.3 \%$ modern}

Comment (HF): with recent activity, $85 \%$ modern, age of duricrust sinter component is $32,020+1920$ if no additional fossil carbonates are present. Otherwise, this is upper limit. 
VRI-443. Villach, Kärnten

Charcoal residue in ceramic vessel from prehistoric culture of Trentino and Südtirol, Italy. Coll 1974 by M Gietler, in Butz-Höhle cave, Mt Graschlitzen $\left(46^{\circ} 35^{\prime} \mathrm{N}, 13^{\circ} 15^{\prime} \mathrm{E}\right), 701 \mathrm{~m}$ asl, Villach, Warmbad, Carinthia, and subm by H Dolenz, Mus Stadt Villach. Sample was embedded in Rotlehm below collapsed roof of cave (Dolenz, 1961). Comment (HD): expected date: Bronze age.

\section{Misling series, Oö}

Remains of wood lifted from bottom of lake Attersee, $20 \mathrm{~m}$ from

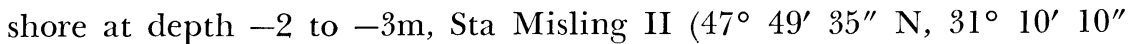
E), Gde Unterach/Attersee, Oö. Coll 1973 and subm by H Offenberger, Bundesdenkmalamt, Vienna.

General Comment: dates different parts of Neolithic lake dwelling sta.

VRI-355. Misling II/1

\section{VRI-356. Misling II/2}

VRI-357. Misling II/3

VRI-358. Misling II/4

$$
4390 \pm 90
$$$$
2440 \text { BC }
$$

$4710 \pm 90$ 2760 BC

$4610 \pm 90$

2660 BC

$4450 \pm 90$

2500 BC

$3450 \pm 80$

$1500 \mathrm{BC}$

\section{VRI-328. Mühlbach, Salzburg}

Wooden bar from point $4635 \mathrm{~m}, 140 \mathrm{~m}$ below surface in so-called adit Keltenstollen of old part of copper mine; fallen in Keltenstollen, later cut by driving adit Arthurstollen, Mühlbach am Hochkönig $\left(47^{\circ} 23^{\prime}\right.$ N, $13^{\circ} 07^{\prime}$ E), Pongau, Salzburg. Coll 1972 by C Eibner, subm by $\mathrm{R}$ Pittioni, Inst Ur Frühgesch, Univ Vienna. Comment (CE): verifies prehistoric age supposed by Kyrle (1916) but doubted by Zschoke and Preuschen (1932).

\section{VRI-400. Kindberg, Steiermark}

$$
230 \pm 70
$$

AD 1716

Wood from under side of roof with paintings depicting Old Testament scenes in small garden house of landowner, A Fürst, Kindberg $\left(47^{\circ} 30^{\prime} \mathrm{N}, 15^{\circ} 27^{\prime} \mathrm{E}\right)$, Styria. Coll and subm by H Stolla, solicitor, Kindberg. Comment (HS): garden house could be mortuary of former medieval Jewish cemetery. De Vries-corrected age is ambiguous: AD 1520 or AD 1650. AD 1520 goes with conception. 
VRI-434. Kühtai, Tirol

Wood (Pinus) from row boat covered with $15 \mathrm{~mm}$ mud, lying at $-26 \mathrm{~m}$ on ground of lake Vorderer Finstertaler See, surroundings of Kühtai $\left(47^{\circ} 12^{\prime} \mathrm{N}, 11^{\circ} 02^{\prime} \mathrm{E}\right)$, Tyrol, alt $2237 \mathrm{~m}$. Coll 1973 and subm by N Schulz, Zoolog Inst, Univ Innsbruck. Comment (NS): date contradicts assumption of medieval fishing boat.

VRI-342. Wien

Wood (Pinus sp) from wooden pipeline of old water supply line, $1.5 \mathrm{~m}$ below surface, Vienna 16 , Ottakringerstra $\beta \mathrm{e}$, corner Deinhardgasse $\left(48^{\circ} 13^{\prime} \mathrm{N}, 16^{\circ} 20^{\prime} \mathrm{E}\right)$. Coll 1971 and subm by $\mathrm{H}$ Bednar, Inst Holzforschung, Hochsch Bodenkultur, Vienna. Comment (HB): tree-ring lower age limit is AD 1722 (Bednar, 1973).

\section{REFERENCES}

Bednar, H, 1973, Die Datierung von alten Holzwasserleitungen durch die Jahresringanalyse: Österr Wasserwirtschaft, $25 \mathrm{Jg}, \mathrm{p}$ 182-185.

Dolenz, H, 1961, Urnenfelderzeitliche und Melaunerkeramik aus Warmbad Villach, Carinthia: Mitt Geschichtsverein, Kärnten, $151 \mathrm{Jg}, \mathrm{p} 383$.

Felber, H, 1971, Altersbestimmungen nach der Radiokohlenstoff methode an Fossilfunden aus dem Bänderton von Baumkirchen (Inntal, Tirol): Gletscherkde Glazialgeol Zeitschr, v 7, p 25-29.

Fliri, F et al, 1972, Weitere Ergebnisse der Forschung am Bänderton von Baumkirchen (Inntal, Nordtirol): Gletscherkde Glazialgeol Zeitschr, v 8, p 203-213.

Franke, H W and Geyh, M A, 1969, Zur C-14-Datierung des Würm-II/III-Interstadials mit Hilfe von Radiokohlenstoffmessungen an Höhlensinter und Schlu $\beta$ folgerungen für die Wasseraltersbestimmung: Eiszeitalter u Gegenwart, v 20, p 72-75.

Geyh, M and Schillat B, 1966, Messungen der Kohlenstoffisotopenhäufigkeit von Kalksinterproben aus der Langenfelder Höhle: Aufschlu $\beta$, v 17, p 315-323.

van Husen, D, 1975, Quatärgeologische Untersuchungen in den östlichen Karawanken: Geol Gesell Wien Mitt, v 66, in press.

Kyrle, G, 1916, Der prähistorische Bergbaubetrieb in den Salzburger Alpen, Beitrag I in Urgeschichte des Kronlandes Salzburg: Österr Kunsttopographie, Wien, v 17 , p $17-27$.

Münnich, K O and Vogel, J, 1959, C-14-Altersbestimmung von Sü $\beta$ wasser-Kalkablagerungen: Naturwiss $46 \mathrm{Jg}, \mathrm{p}$ 168-169.

Patzelt, G, 1973, Die postglazialen Gletscher- und Klimaschwankungen in der Venedigergruppe (Hohe Tauern, Ostalpen): Z Geomorph N F, suppl v 16, p 25-72.

Zschoke, K and Preuschen, E, 1932, Das urzeitliche Bergbaugebiet von MühlbachBischofshofen: Mat z Urgeschichte Österreichs, Wien, v 6, p 14-17. 